\title{
A statistical analysis of population variability in Bronze Turkey considering gene conservation
}

\begin{abstract}
Genetic variability is very important in small populations. We examined an indigenous Bronze Turkey population which is bred for gene conservation in order to see if the current mating system maintains genetic variability. The present generation was surveyed using microsatellite markers and a computer model was used to simulate changes in the population over 100 generations. The data was analysed using the concept of entrophy from information theory instead of genetic variance so that we could measure genetic variability more accurately. The results indicate that the breeding method currently in use, rotational line mating, is acceptable with respect to preserving genetic variability, but new selection methods may provide additional protection against the loss of alleles.
\end{abstract}

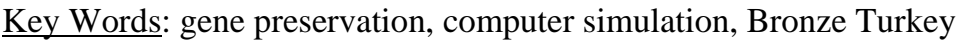

\section{Zusammenfassung}

Titel der Arbeit: Statistische Analyse der Variabilität einer Bronzeputenpopulation unter dem Aspekt des Generhalts

Die genetische Varianz ist bei kleinen Populationen besonders wichtig. Untersucht wurde eine für die Generhaltung gezüchtete bodenständige Population von Bronzeputen um festzustellen, ob das derzeit angewandte Paarungssystem die genetische Varianz erhält. Mit Hilfe von Satellitenmarkern wurde die gegenwärtige Generation erfasst und durch eine Computersimulation die Erwartungen für die folgenden 100 Generationen analysiert. Zur besseren Beurteilung der Entwicklung wurde bei der Datenanalyse anstelle der genetischen Varianz, die in der Informationstheorie verwendete Enthropie genutzt, wodurch eine genauere Beurteilung der genetichen Varianz möglich wurde. Die Ergebnisse zeigen, dass die Nutzung des Rotationsprinzips bei der Paarung der Linien in Bezug auf die Erhaltung der genetischen Varianz geeignet ist, jedoch mit neuen Selektionsmethoden besser dem Allelverlust entgegen gewirkt werden könnte.

Schlüsselwörter: Generhaltung, Computersimulation, Bronzepute

\section{Introduction}

An important goal of gene preservation is to maintain genetic variability. Too small population size will result in a number of problems: inbreeding can lead to inbreeding depression and genetic drift, to a loss of alleles. FRANKHAM (1995) collected the effects wich influence the genetical variation of a small population, i.e. initial heterozygosity, number of generation, effective population size. Earlier, blood group tests were used to avoid inbreeding (PAPP et al., 1999). Recently molecular techniques have replaced the blood group test in gene conservation. NORTIER et al. (2002) examined the genetic diversity of indigenous Sanga Cattle in Namib with microsatellite techniques. HISATO et al. (1995) also used microsatellite markers in a small population. They surveyed the level of relationship and inbreeding based on the gained information and computer simulation. 
This article presents the results of a study of an indigenous Bronze Turkey population which is bred for gene conservation. The aim of the study was to evaluate the suitability of the present mating algorithm for maintaining the genetic variability of this population.

\section{Materials and Methods}

The population on the experimental farm of the Debrecen University consists of 211 turkeys: 38 toms and 173 hens. Breeders keep the population size constant across generations. The animals are kept in 11 lines, each line consisting of $3-4$ toms and 12 - 16 hens. The females who hatch will be the next generation of females of this line. The males who hatch will be the next generation of males of the neighbouring line. Hens lay 19 eggs on average. Turkeys live an average of two years. In the reproduction cycle, the animals mate at random within each line. All of the eggs are hatched, breeders move the retained males to the next line and from the final line to the first. The breeders try to maintain genetic variation with this male rotation.

The genetic variability of 144 Bronze Turkeys from the gene reserve population was surveyed using microsatellite markers.

Fifty-eight chicken-specific microsatellites, also highly polymorphic in turkeys (REED et al., 2000) were selected for examination. These markers were tested on 10 turkey (3 toms and 7 hens) DNA samples prepared from blood. Each primer pair was screened at three different annealing temperatures (65-55; 63-53 and 61-51) and three different concentrations of $\mathrm{MgCl} 2(2 \mathrm{mM} ; 2.5 \mathrm{mM}$ and $3 \mathrm{mM})$. PCR reactions $(5 \mu \mathrm{l}$ total volume) contained $0.1 \mathrm{U}$ Taq Polymerase; x10 buffer, $0.8 \mathrm{mM}$ of each dNTP; $200 \mathrm{nM}$ forward and reverse fluorescently labelled primers $0.001 \mu \mathrm{g}$ BSA; and 10 ng template DNA. The amplification was performed using a PTC-200 DNA Engine thermal cycler and a 96 well format (MJ Research). Touch down PCR included a 3 min. at $95^{\circ} \mathrm{C}$ preamplification of denaturation. Followed by 10 cycles of $30 \mathrm{sec}$. at $95^{\circ} \mathrm{C}, 30 \mathrm{sec}$. at $65 / 63 / 61^{\circ} \mathrm{C}$ and each cycle decreased by $1^{\circ} \mathrm{C} /$ cycle, and $30 \mathrm{sec}$. at $72^{\circ} \mathrm{C}$. That was followed by other 25 cycles with annealing temperature of $55 / 53 / 51^{\circ} \mathrm{C}$. The PCR was finished with a final elongation of $5 \mathrm{~min}$. at $72^{\circ} \mathrm{C}$. The PCR products were separated using an ABI 310 Genetic Analyser, sized by the application of TAMRA 500, and evaluated by using GeneScan Analysis and Genotyper Software.

We developed a set consisting of 8 fluorescently labelled microsatellites (ADL0149, ADL0150, DL0266, ADL0272, ADL0292, ADL0293, MCW0018, MCW0080). To geneotype an individual, these microsatellites were amplified in three multiplex PCRs and were analysed in a single capillary gel electophoresis run of ABI310.

The base of the simulation was the current population. The program was written and executed using MATLAB (1992).

The effective population size was calculated as:

$N_{e}=\frac{4 N_{m} N_{f}}{N_{m}+N_{f}}=108$ (FALCONER and MACKAY,1996)

and it was kept constant from generation to generation in the simulation.

Since the base population was homozygous with respect to the second locus, we recorded the simulated values for seven loci. Table 1 contains the frequency of base alleles. 
We began by assaying the samples, and then programmed the applied mating and selection systems. Our goal was to derive a distribution of the population characteristics after one-hundred generations. We simulated inheritance over onehundred generations four-hundred times and compared the results with the characteristics of the original population.

Table 1

Frequency of alleles in the base population (Allelfrequenz in der Ausgangspopulation)

\begin{tabular}{lcc}
\hline Locus & Alleles & Frequency of alleles \\
\hline ADL0292 & 118 & 0.0035 \\
& 128 & 0.9444 \\
& 130 & 0.0035 \\
ADL0293 & 132 & 0.0347 \\
& 81 & 0.0038 \\
ADL0272 & 99 & 0.9923 \\
& 108 & 0.0038 \\
ADL0149 & 160 & 0.7698 \\
& 168 & 0.2302 \\
& 222 & 0.1750 \\
ADL0266 & 224 & 0.8214 \\
& 228 & 0.0036 \\
ADL0150 & 84 & 0.0075 \\
MCW0080 & 96 & 0.7239 \\
& 104 & 0.2686 \\
& 120 & 0.0074 \\
& 138 & 0.9926 \\
\end{tabular}

In the course of simulation we calculated the Shanon entrophy value, which is used in information theory. Shanon's formula is:

$$
H=H(\xi)=-\sum_{x \in X} p(x) \log _{2} p(x),
$$

where $\xi$ is a discrete random variable with $p=\{p(x) ; x \in X\}$ distribution, $X$ is the set of the signs of information source, $\mathrm{x}$ is an element of this set to measure the amount of information. The values of the $\xi$ are signs from the information source (BARÓTI et al., 1993). Logarithms of other than base 2 can be substituted into this formula without changing the entrophic properties; we applied the natural logarithm.

When probabilities are small and distributed over a great number of alternatives statistical entropy is a measure of variation. "Variation" is the qualitative analog of "variance" as used in the statistics of ordered (interval scale) variables. The quantity is zero when all events are of the same kind, $\mathrm{p}(\mathrm{x})=1$ for any one $\mathrm{x}$ of $\mathrm{X}$ and is positive otherwise. Its upper limit is $\log _{2} \mathrm{~N}$ where $\mathrm{N}$ is the number of categories available and the distribution is uniform over these, $\mathrm{p}(\mathrm{x})=1 / \mathrm{N}$ for all $\mathrm{x}$ of $\mathrm{X}$. The statistical entropy measure is the most basic measure of information theory (KRIPPENDORFF, 2004).

In practice, the variance is usually used to measure genetic variability. We chose the entrophy value instead, because it is a more exact measure of the variability of genes. The variance is the degree of fluctuation around the expected value of a random variable, so it is depends on the values given to genes. In contrast, entrophy depends only on the frequency of alleles and is independent of this assignment. In the case of the gene preservation problems, the application of entrophy is expedient because it features the population very well. When the frequency of an allele decreases, entrophy 
decreases as well. When entrophy is maintained or increased, the probability of the loss of alleles is reduced. We calculated the entrophy at each locus, a non-negative number dependent on the number of alleles in the locus and the relative frequency of alleles. This value is minimized at zero when the population is homozygous; when only one allele can be found at each locus. It is maximized when the frequency of alleles are equal at each locus.

Tables 2 and 3 contain the entrophy value if two or three alleles are found in a locus and if the frequency of alleles is changed.

Table 2

Entrophy values in the two-allele case (Allelanreicherung im Fall der 2 Allele)

\begin{tabular}{lcl}
\hline & Frequency of alleles & Entrophy \\
\hline 0.1 & 0.9 & 0.325083 \\
0.2 & 0.8 & 0.500402 \\
0.3 & 0.7 & 0.610864 \\
0.4 & 0.6 & 0.673012 \\
0.5 & 0.5 & 0.693147 \\
\hline
\end{tabular}

Table 3

Entrophy values in the three-allele case (Allelanreicherung im Fall der 3 Allele)

\begin{tabular}{|c|c|c|c|}
\hline & Frequency of alleles & & Entrophy \\
\hline 0.1 & 0.1 & 0.8 & 0.639032 \\
\hline 0.1 & 0.2 & 0.7 & 0.801819 \\
\hline 0.1 & 0.3 & 0.6 & 0.897946 \\
\hline 0.1 & 0.4 & 0.5 & 0.943348 \\
\hline 0.2 & 0.2 & 0.6 & 0.950271 \\
\hline 0.2 & 0.3 & 0.5 & 1.029653 \\
\hline 0.2 & 0.4 & 0.4 & 1.054920 \\
\hline 0.3 & 0.3 & 0.4 & 1.088900 \\
\hline 0.33 & 0.33 & 0.33 & 1.098612 \\
\hline
\end{tabular}

Another simulation program was used to ascertain how quickly a rare allele was eliminated from the population. We examined instances in which one, two or three animals in the base population had the rare allele (frequencies of 0.0035, 0.007, and 0.0105). As the bearer animals must be differentiated by sex, there were nine separate cases for study. In every case a simulation of one-hundred generations was performed four-hundred times.

Use of simulation software raises the difficult question of generating random numbers. The random number generator built into MATLAB is based on the linear congruential method. The basic algorithm is: seed=(77 seed) $\bmod (231-1)($ MATLAB, 1992). To avoid the repetition of data, we changed the seed of the random number generator after every 100 runs.

\section{Results}

The population was in Hardy-Weinberg equilibrium at seven loci. (In the 2. locus the population was homozygote.) Using the $\chi 2$ test, statistical analysis showed that this result was significant at the $5 \%$ significance level (Table 4).

The genotype data from the simulations were used to calculate the expected $(\mathrm{He}=$ $0.165)$ and the real $(\mathrm{Ho}=0.164)$ heterozygosity values. These low values are typical in turkeys (KOROM et al, 2003). 
In our population, taking the number of alleles and loci into account, entrophy would be maximized if the frequency of alleles were 0.25 at the first locus, 0.33 at the second, fourth and fifth loci, and 0.5 at the third, sixth and seventh loci. In this instance, the sum of the entrophy values would be 6.76. In the four hundred simulations performed, the observed value ranged, with one exception, from 1.6 to 2.9, with an average of 2.17 .

Table 4

The $\chi^{2}$ test for checking the Hardy-Weinberg equilibrium ( $\chi 2$ Test zur Kontrolle des Hardy-Weinberg Aquilibriums)

\begin{tabular}{lccc}
\hline Loci & Calculated $\chi 2$ value & $\chi 2$ value at 5\% significance level & Degree of freedom \\
\hline 1 & 0.2764 & 7.81 & 3 \\
2 & The population was homozygote in this locus. & & 2 \\
3 & 0.0078 & 5.99 & 1 \\
4 & 0.0918 & 3.84 & 2 \\
5 & 1.2698 & 5.99 & 2 \\
6 & 1.6868 & 5.99 & 1 \\
7 & 0.0075 & 3.84 & 1 \\
\hline
\end{tabular}

The loss of alleles. During the simulations we recorded the generation in which an allele was lost (the frequency of the allele became zero). We observed how many generations it took for the frequency of an allele to become zero if just one, two or three turkeys in the population have a rare allele. The sexes had to be analyzed separately as males and females have different probabilities of transmitting their genes. The probability that a rare allele (a frequency of 0.0035 ) of a male will be inherited:

$$
P(A)=1-P(\bar{A})=1-\frac{\left(\begin{array}{c}
150 \\
1
\end{array}\right)}{\left(\begin{array}{c}
180 \\
1
\end{array}\right)} \approx 0.166
$$

Every tom mated 3 hens. Every hen had 20 eggs. The A event mean, that a tom's given allele is inherited. In the calculation we used the opposite event - is not inherited. In the denominator the $\left(\begin{array}{c}180 \\ 1\end{array}\right)$ means: 9 hens times 20 eggs is equal 180 eggs, and we chose only 1 from it. In the numerator $\left(\begin{array}{c}150 \\ 1\end{array}\right)$ means, that in a line there are 150 eggs without the rare allele (approximately).

The same calculation for a female: similar than above, except $\left(\begin{array}{c}170 \\ 1\end{array}\right)$ means, that in a line there are 170 eggs without the rare allele (approximately).

$$
P(B)=1-P(\bar{B})=1-\frac{\left(\begin{array}{c}
170 \\
1
\end{array}\right)}{\left(\begin{array}{c}
180 \\
1
\end{array}\right)} \approx 0.055
$$

Table 5 contains the results after 400 simulation runs. 
Table 5

The result of the simulation (Ergebnisse der Computersimulation)

\begin{tabular}{|c|c|c|c|c|c|c|}
\hline $\begin{array}{l}\text { Frequency of } \\
\text { allele in the } \\
\text { base } \\
\text { population }\end{array}$ & $\begin{array}{l}\text { Allele } \\
\text { carrier }\end{array}$ & $\begin{array}{l}\text { Average } \\
\text { allele } \\
\text { retention } \\
\text { period } \\
\text { (number of } \\
\text { generations) }\end{array}$ & $\begin{array}{l}\text { Percent of cases } \\
\text { the allele was lost } \\
\text { in the first } \\
5 \text { generations } \\
\text { (10 years) }\end{array}$ & $\begin{array}{l}\text { Percent of cases } \\
\text { the allele } \\
\text { reamined after } \\
25 \text { generations } \\
\text { (50 years) }\end{array}$ & $\begin{array}{l}\text { Percent of cases } \\
\text { the allele } \\
\text { remained after } \\
100 \text { generations } \\
\text { (200 years) }\end{array}$ & $\begin{array}{l}\text { Standard } \\
\text { deviation } \\
\text { (generations) }\end{array}$ \\
\hline \multirow[t]{2}{*}{0.0035} & 1 female & 4.4 & $85.5 \%$ & $2.8 \%$ & $0.0 \%$ & 11.2 \\
\hline & 1 male & 40.3 & $21.5 \%$ & $48.5 \%$ & $6.5 \%$ & 37.1 \\
\hline \multirow[t]{3}{*}{0.007} & $\begin{array}{l}2 \\
\text { females }\end{array}$ & 7.6 & $71.0 \%$ & $6.8 \%$ & $0.3 \%$ & 14.4 \\
\hline & $\begin{array}{l}1 \text { female } \\
1 \text { male }\end{array}$ & 43.8 & $19.8 \%$ & $53.3 \%$ & $7.8 \%$ & 38.1 \\
\hline & 2 males & 57.0 & $5.5 \%$ & $72.0 \%$ & $1.3 \%$ & 34.4 \\
\hline \multirow[t]{4}{*}{0.0105} & $\begin{array}{l}3 \\
\text { females } \\
2\end{array}$ & 24.6 & $43.5 \%$ & $30.5 \%$ & $1.0 \%$ & 30.8 \\
\hline & $\begin{array}{l}\text { females } \\
1 \text { male }\end{array}$ & 45.2 & $15.3 \%$ & $60.0 \%$ & $5.3 \%$ & 34.9 \\
\hline & $\begin{array}{l}1 \text { female } \\
2 \text { males }\end{array}$ & 63.3 & $6.3 \%$ & $76.0 \%$ & $24.0 \%$ & 36.6 \\
\hline & 3 males & 78.3 & $1.0 \%$ & $88.0 \%$ & $33.8 \%$ & 29.9 \\
\hline
\end{tabular}

\section{Discussion}

Irrespective to the small population size (144 individuals) the population was in Hardy-Weinberg equilibrium. The divison of the population into lines and migration between lines did not change the equilbrium. We did not find either a shortage or excess of heterozygotes suggesting that the population is mating in a nearly random fashion. When samples from subpopulations have diverged sufficiently we can observe an overall defiency of heterozygotes. This is the Wahlund effect (McDONALD, 2002). PARDUCCI et al. (1996) studied Abies alba populations. They found that all the populations showed a deficiency of heterozygotes. Partial inbreeding due to restricted pollen dispersal and Wahlund effect could be responsible for this situation. In our case the Wahlund effect was not observed, probably as a result of the continuous migration between lines. The genetic structure of natural populations of cats was examined in Spain and in upper midwestern USA by RUIZ-GARCIA and KLEIN (1997) found different results in two cat populations. The Catalan populations were in reasonably good agreement with expectations of Hardy-Weinberg equilibrium while the North American populations showed some evidence of the Wahlund effect (overall heterozygote deficiency indicating population substructuring).

The simulations bear out our assumption that gender greatly influences the probability of losing a rare allele using the present mating system. When from the 144 turkeys only one hen had a rare allele, it was lost within five generations in $85.5 \%$ of the cases and was retained for twenty-five or more generations only $2.8 \%$ of the time. When a male had the rare allele, the values were $21.5 \%$ and $48.5 \%$, respectively (See Figures 1, 2). DIETL and LANGHAMMER (1997) used an one-locus-model for simulation with 80 alleles. They compared different mating systems (random mating, negative assortative mating, positive assortative mating, a mating system wich provided the minimal rate of inbreeding). In their study it was showed, that the loss of allele were $79 \%-94 \%$ in the 15 generation depending on the mating system. In an other simulation study PRIKRYL et al., (1987) the allele loss decreased rapidly for alleles with a 
frquency of approx. 0.05, for 10 mating individuals. The initial allele frequency (at 2 or 5 loci) was 0.01-0.99 and from 5-25 individuals were selected a pair for the next generation.

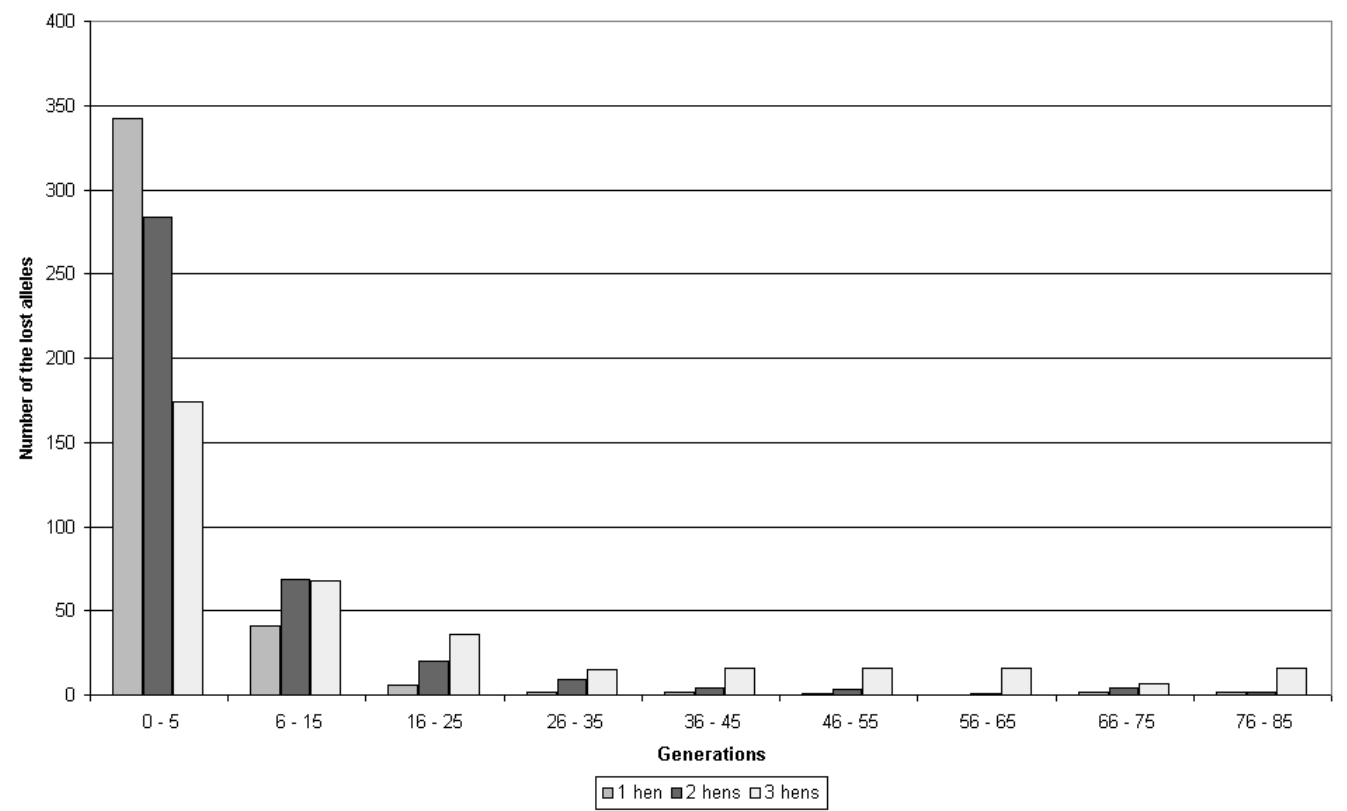

Fig. 1: Generation in which the allele was lost, when the base population the gene owner were 1, 2 or 3 hens (400 runs) (Generation in der Alleleverlust stattfand, wenn in der Ausgangpopulation 1, 2 und 3 Hennen das Allel hatten; Mittel aus 400 Wiederholungen.))

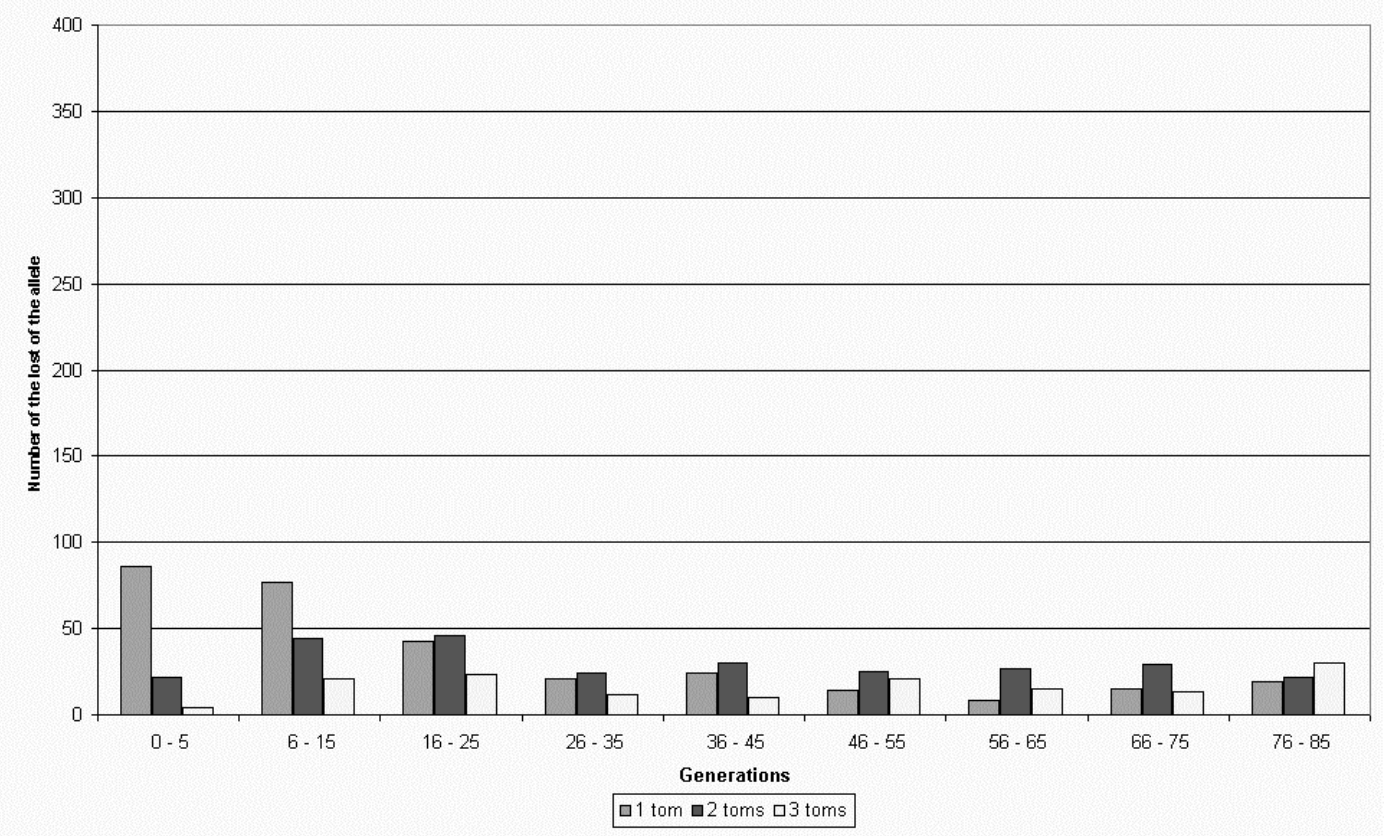

Fig. 2: Generation in which the allele was lost, when the base population the gene owner were 1, 2 or 3 males (400 runs) (Generation in der Alleleverlust stattfand, wenn in der Ausgangpopulation 1, 2 und 3 Puter das Allel hatten; Mittel aus 400 Wiederholungen))

The average number of generations that a rare allele survived is presented in Table 5 . The values presented should be interpreted in light of the fact that only one-hundred generations were simulated. In those runs that the allele remained after one-hundred 
generations, the generation in which it was lost could not be observed; a value of 100 was assigned in this instance. This has no impact on the one-hen case, where the allele was lost in every simulation run, but has a marked effect when the allele is present in three males. Here the allele survived in one-third of the runs, meaning that the estimated survival period of 78.3 generations is an underestimate.

We found large differences in the standard deviation of the survival period. When the frequency of an allele was 0.0035 and a hen had this rare allele, the standard deviation of this value was 11.2 generations. When a tom had the allele, the corresponding value was 37.1 generations.

\section{Conclusion}

The results indicate that the rotational mating system preserves genetic variability. The observed entrophy was stable across generations at close to the initial value. It must be emphasized, however, that the large standard deviations observed indicate that chance can have a marked impact on the outcomes, and can result in the loss of an allele in a given case.

If, in a similarly small population, a rare allele is present in only one or two animals (the original frequency of the allele is less than 0.01), and preservation is desired, we should pay particular attention to these animals. It is not enough to leave retention of these genes to chance, preservation requires keeping more offspring of these animals during the selection performed to control the size of the population.

The standard deviations observed in the results indicate that even in cases, where the probability of losing a gene is high in males, in practice, it can be easily lost due to chance.

\section{References}

BARÓTI, GY.; BOGNÁR, J.; FEJES TÓTH G.: Probability theory (Valószínüségszámítás.) Nemzeti Tankönyvkiadó (1993) 255

DIETL, G.; LANGHAMMER, M.: Conservation of rare breeds of animals - objectives and possibilities. Arch. Tierz., Dummerstorf 40 (1997) Sonderheft, 135-141

FALCONER, D.S.; MACKAY T.F.C.:

FRANKHAM, R.: Introduction to Quantitative Genetics. (1996) Fourth edition

HISATO T.; TARO O.; TSUTOMU F.: Use of marker information to maintain variability in small population. Animal Genetic Resources International Workshop, Tsukuba, Japan. , (1995)

KOROM, E.; NAGY, T.; KOVÁCS B.: Use of microsatellite of hen for discribing of turkey population. (Tyúk mikroszatellitek felhasználása pulyka populáció genetika jellemzésére.) V. Magyar Genetika Kongresszus, (2003) poszter. Siófok. MATLAB Hungary

Reference Guide The MATH WORKS INC., (1992) 401

McDONALD, D. http://www.uwyo.edu/dbmcd/molmark/lect05/lect5.html (09.03.2004)

NORTIER, C.L.; ELS, J.F.; KOTZE, A.: Genetic diversity os indigenous Sanga Cattle in Namibia using microsatellite markers. 7th World Congress in Genetic Applied to Livestock Production. Montpellier, France (2002)

PAPP, M.; KOPPÁNY, G.; SZALAY, I.:

One decade of experiments on immunogenetic studies (blood typing) used for gene conservation of Hungarian native chicken breeds. Állattenyésztés-és-Takarmányozás. 48 (1999) 6, 791-793 
PARDUCCI, L.; SZMIDT, AE.; VILLANI, F.; WANG XIAORU; CHERUBINI, M.; WANG, XR.:

Genetic variation of Abies alba in Italy. Hereditas-Landskrona. 125 (1996) 1, 11-18

PRIKRYL, I.; LINHART, O.; TIEWS, K.:

Simulating the allele frequencies for optimalization of genetic improvement by group line gynogenesis. Selection, hybridization, and genetic engineering in aquaculture. Volume1. Proceedings of a worldsymposium, Bordeaux, June 27-30, 1986. (1987), 431-436

REED, K.M.; MENDOZA, M.K.; BEATTIE, C.W.:

Comparative analysis of microsatellite loci in chicken and turkey. Genome, 43 (2000), 796-802

RUIZ-GARCIA, M.; KLEIN, K. K.:

Genetic structure of populations of the domestic cat in Catalonia (Spain) and upper midwestern USA: a microgeographic and macrogeographic study. Journal-of-Genetics. 76 (1997) 2, 99-115

Received: 2003-09-29

Accepted: 2004-06-18

Authors addresses

SZILVIA SZÖKE, professor's assistant

University of Debrecen, Centre of Agricultural Sciences, Dept. of Statistics,

Debrecen

Pf. 36.

4015

Hungary e-mail: szilvia@helios.date.hu

ISTVÁN KOMLÓSI, associate professor

University of Debrecen, Centre of Agricultural Sciences,

Dept. of Animal Husbandry, Breeding and Nutrition

Debrecen

Pf. 36.

4015

Hungary

EDIT KOROM, Phd student

Agricultural and Biotechnological Research Centre, Institute of Animal Biology

Gödöllő

Szent-Györgyi Albert u.4.

2100

Hungary

MÁRTON ISPÁNY, associate professor

University of Debrecen, Institute of Informatics,

Dept. of Applied Mathematics and Probability

Debrecen

Egyetem tér 1.

4001

Hungary

SÁNDOR MIHÓK, professor

University of Debrecen, Centre of Agricultural Sciences,

Dept. of Animal Husbandry, Breeding and Nutrition

Debrecen

Pf. 36.

4015

Hungary 